\title{
プリント基板絶縁層内部の空間電荷の観測
}

\author{
正員 福永 香 (通信総研) \\ 正員 岡本 健次（富士電機総研）
}

\author{
正員 前野 恭 (通信総研) \\ 正員 芳賀弘二(富士電機総研)
}

\section{Space charge observation of a metal base printed wiring board}

\author{
K. Fukunaga, Member, T. Maeno, Member (Communications Research Laboratory) \\ K. Okamoto, Member and K. Haga, Member (Fuji Electric Corporate Research and Development Ltd.)
}

\begin{abstract}
Since a metal-base printed wiring board (PWB) with superior thermal conductivity has been widely used in power electronics products, high reliability is required at high electric field. Many reports have already covered 'surface' copper ionic migrations on PWBs which occur short-circuits on the board. The migration growing into the depth direction of a insulation layer has been clearly observed recently, and it is revealed that the growth depends on the ionic impurities of the resin.

We measured space charge behaviour in the insulation layer to know the relationship between the internal space charge and the ionic migration. The results suggest that internal negative charges are generated at high temperature with high humidity, and that a conductive region is formed near a copper electrode under dc electric field.
\end{abstract}

キーワード：金属ベースプリント基板，銅イオンマイグレーション, 空間電荷, パルス静電応力法

\section{1. 概 要}

パワーエレクトロニクス分野の機器では, 放熱効果の高 い金属ベースプリント配線板（以下プリント基板と略記） が多く用いられている。この基板はアルミニウム等のベー ス金属, 無機立填剂入りエポキシ樹脂等の絶縁層, 鉰箔電 極の 3 層で構成されている。近年, 各種電子部品の小型化, 高性能化が進み,プリント基板の絶縁層には $1 \sim 3 \mathrm{kV} / \mathrm{mm}$ という比較的高い電界が加わるようになり，その絶縁信頼 性が重要視されている(1)。

従来より配線間の短絡を引き起こす絶縁層表面での銅イ オンマイグレーション少化については精力的に検討されて きたが, 最近では絶縁層の厚さ方向にも銅イオンマイグレ 一ション（以下マイグレーションと略記）が発生し，絶緑 破壊の原因となることが明らかになってきた。直流課電時 の絶稼層内部への銅マイグレーションの進展には樹脂内部 の不綶物イオンが関与していると考えられ, 化学的な分析 に基づき検討が進んでいる(2,3)。

一方，空間電荷分布測定技術の向上により，厚さ $150 \mu \mathrm{m}$ 程度の薄い樹脂内部の不純物イオンの直流課電時における 挙動が観測できるようになった(4,5)。そこで,パルス静電応 力法(s)を用いて, プリント基板絶縁層内部の空間電荷挙動
を観測し，絶縁性能の評価に適用できるかについて検討し た。その結果, 試料内部の構造が空間電荷分有に影䇾を及 ぼすこと，加湿によりプリント基板絶縁層内部に負電荷が 生成されること, 直流電圧を課電することにより anode 近 傍に導電性の高い領域が形成されることなどが明らかに なった。プリント基板絶縁層の空間電荷分布の観測例は従 来実施されたことがないため，本論文では観測時の問題点 等について述べた後, 少化前, および加速少化試験後の空 間電荷分布の変化について観測結果を中心に報告する。

\section{2. 試料および寒験方法}

プリント基板試料は図 1 に示すようにアルミニウム, 無 機充填剂入りエポキシ樹脂, 銅䈃電極の 3 層構造で, 銅簿 電極以外の部分にはソルダーレジスト層が形成されている。 観測対象である絶縁層内部の空間電荷挙動を観測するのに 適した試料を選択するため, 銅䈃, ソルダーレジスト層等 が空間電荷測定に与える影響について検討した。

絶縁層のエポキシ樹脂には組成, 製造工程の異なる 2 種 類の試料（試料(1)：充填材シリカ, $\varepsilon_{\mathrm{r}}=4.8, \tan \delta=2.9 \%$, 試 料(2)：充填材アルミナ， $\varepsilon_{\mathrm{r}}=7.6, \tan \delta=0.47 \%$ )を用いた。 
また課電条件は，全ての実験において銅電極側に正の高 電圧,アルミベース側が接地となるように印加した。測定結 果の空間電荷分布波形を示す図中には銅電極側を anode, ア ルミベース電極側を cathode と記した。

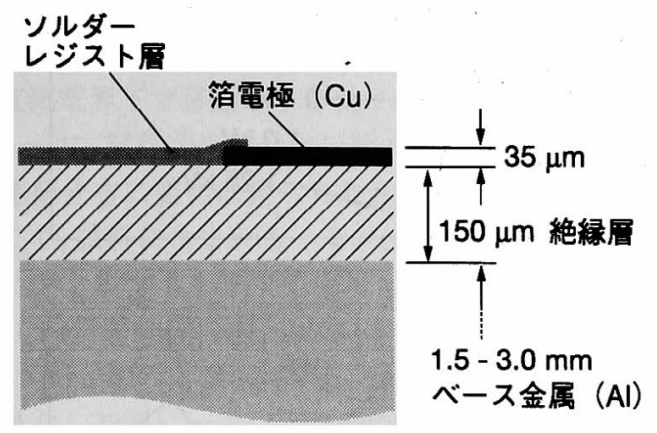

図 1 一般的なプリント基板の構造

Fig. 1 An example of a metal-base printed wiring board.

\section{3. プリント基板試料の構造と空間電荷分布}

$<3 \cdot 1>$ 箔電極の影霎 劣化前の試料(1)に直流電圧 1.25 $\mathrm{kV}$ を印加した時の空間電荷分布を図 2 に示す。銅電極を蒸 着で形成した場合にはアルミ電極 (cathode) 側, 銅電極 (anode) 側とも信号が得られた。しかし，箔電極の場合には anode 側の信号が観測できない。この原因は，樹脂と箔電極 の音響インピーダンスの不整合による弾性波の反射が影響し たためと考えられる。

<3.2> ソルダーレジスト居の影䈏劣化前の試料(1)を 用い, 䈃電極の無い部分に直流電圧 $1.25 \mathrm{kV}$ を印加すると, 図 3のようにソルダーレジスト層の部分に大きな負電荷があら われ，ほとんどの電界がソルダーレジスト層にかかるような 分布を示す。この結果も興味深いが, エポキシ樹脂絶縁層内 部の電荷挙動には直接関係しないと考えられる。

<3.3> 絶縁居内部の界面の影䇾絶縁層が複数の層か ら形成された試料(2)では図 4 (a)の SEM 画像にみられるよう に絶縁層内部に界面が存在する。この試料に直流電圧 $1.25 \mathrm{kV}$ を印加すると界面の位置に信号が現れる。界面部分は, 局所 的に誘電率, 抵抗率が異なっている可能性が高く, エポキシ 内部の層構造を非破壊で知るという点では有効であるが, 空 間電荷分布も複雑となる。

\section{4. 絶緑層内部の不純物イオンと空間電荷分布}

$<4 \cdot 1>$ 初期状態での絶縁首内部の空間電荷挙動

劣化前の試料(1)に直流電圧を印加した場合の空間電荷分布 を図 5 に示す。(a)は0.4, 0.8, 1.0, $1.25 \mathrm{kV}$ において，各電圧に 昇圧後約15秒で観測した結果であり,(b)は(a)の特性を測定後 に接地し，約 10 秒後および 60 秒後において観測した結果で ある。cathode 近傍に正, anode近傍に負の電荷が見られ, 接 地後の波形からもわかるように, 正電荷の方が多い。この cathode近傍の正電荷は課電中の時間経過にともない徐々に増 加した。そこで, 各電圧で空間電荷分布に変化が見られなく

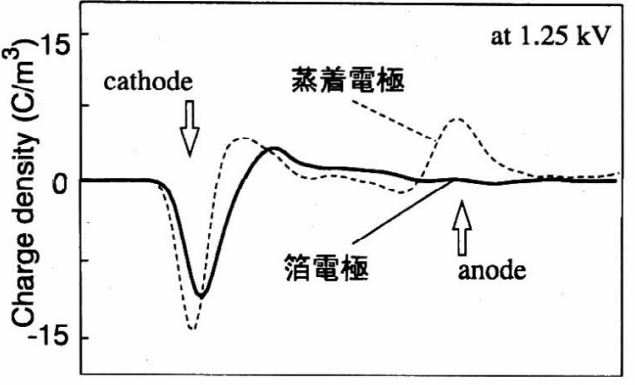

図 2 䈃電極が空間電荷分布に与える影響 (試料(1)，未劣化， at $1.25 \mathrm{kV}$ )

Fig. 2 Influence of thin metal electrode on the space charge distribution.

(Sample 1, before ageing, at $1.25 \mathrm{kV}$ )

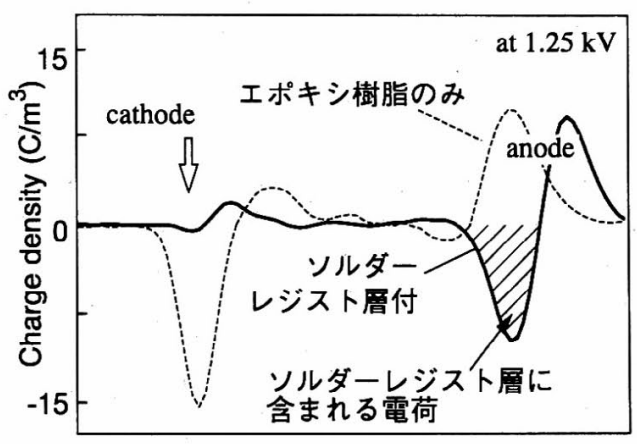

図 3 ソルダーレジスト層で形成される電荷分布 (試料(1)，末劣化， at $1.25 \mathrm{kV}$ )

Fig. 3 Influence of thin solder regist on the space charge distribution.

(Sample 1, before ageing, at $1.25 \mathrm{kV}$ )

(a) 試料断面のSEM像

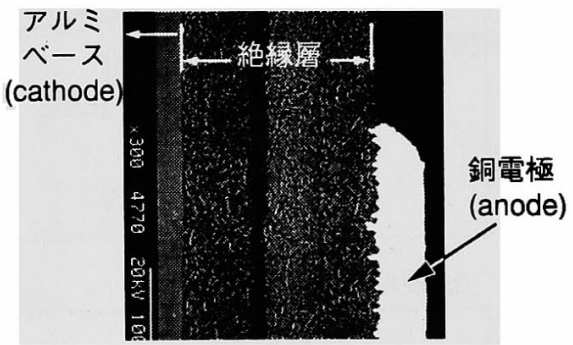

(b) 空間電荷分布

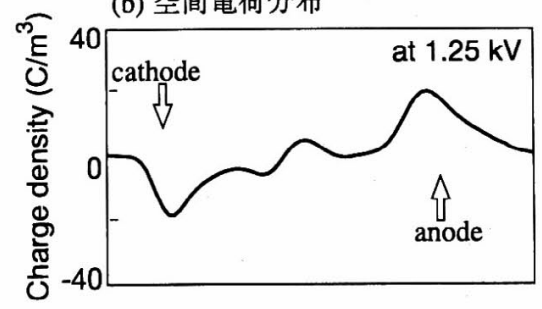

図 4 絶縁層内部界面の空間電荷形成への影響

Fig. 4 Influence of internal layers on the space charge formation.

(Sample No.2, before ageing, at $1.25 \mathrm{kV}$ ) 
なるまで一定電圧に保持した後に昇圧するという条件で観測 したところ,各電圧で図 6 (a)のような空間電荷分布が得られ た。図 6 (b)恃，図 6 (a)の特性を測定後に接地し, 約 10 秒後 および60秒後において観測した結果である。この結果から劣 化前の樹脂中には主に正の電荷が存在し, $1 \mathrm{kV}$ 以上の直流課 電時に負電極側へ移動することが明らかになった。図 $6(\mathrm{a})$ の 空間電荷分布をもとに, 課電中の両電極近傍の蓄積電荷量を 算出したところ，図 7 のように cathode 側の正の電荷量 $(0)$ が $0.8 \mathrm{kV}$ と $1.0 \mathrm{kV}$ の間で急増していることが明らかになっ た。直流電界下で逆極性の電極に向かって移動する電荷は内 部のイオンによるものと考えられ，それが移動可能となる電 界にはしきい值が存在すると考えると，今回の実験条件で は，その值が約 $1 \mathrm{kV}(6.7 \mathrm{kV} / \mathrm{mm})$ であると推測される。しか し，そのしきい値はイオンの種類, 材料の種類, 温度, 湿度 等の影響をうけると考えられるため,詳細はさらに条件を変 えた実験を行い明らかにしていく予定である。ここで，プリ ント基板の絶粶性能の評価には一般に実際の使用条件より高 い電圧を印加する加速劣化試験が行なわれているが,この実 験結果からは内部電荷の挙動は印加されている電界によって 異なっている。この現象は劣化試験の電圧加速の等価性を検 討する上でも重要な意味を持つと考えられる。

一方, 試料(2)の場合には一定電圧をかけた場合の経時変化 は見られず，図８に示すように印加電界にほほ比例して変化 している。前述のように内部構造に依存した信号が観測され るが, 不純物イオンによると思われる電荷の蓄積, 增加は見 られなかった。

(a) $\mathrm{dc}$ 課電中

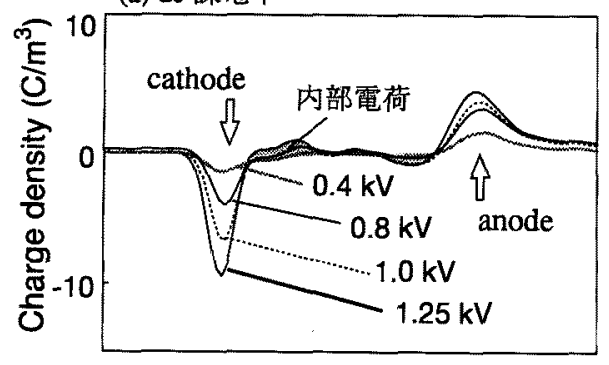

(b) 接地後

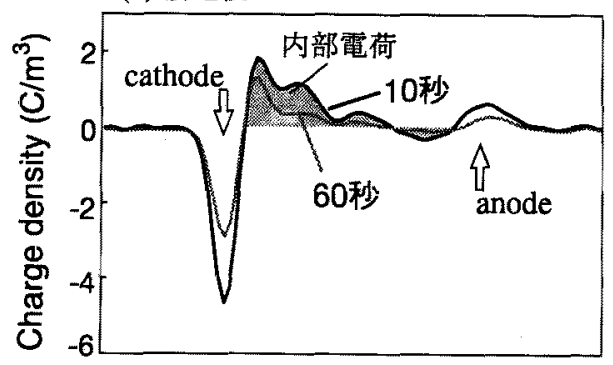

図 5 劣化前の試料(1)に招ける空間電荷分布 -1 (a) $\mathrm{dc}$ 課電中 (b) 接地後

Fig. 5 Space charge distribution in sample 1 before ageing-1. (a) under dc bias voltage (b) after the short-circuits

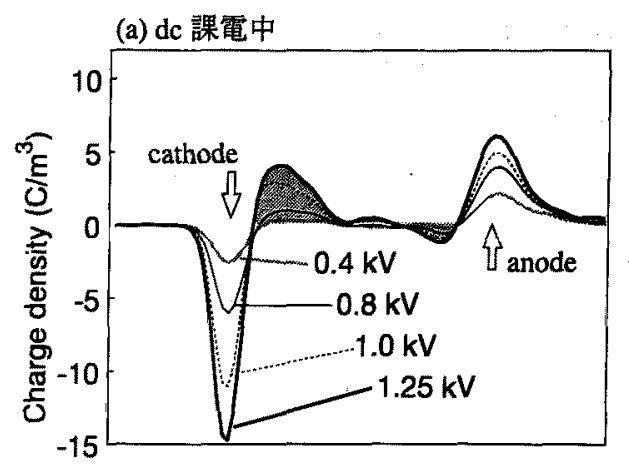

(b) 接地後

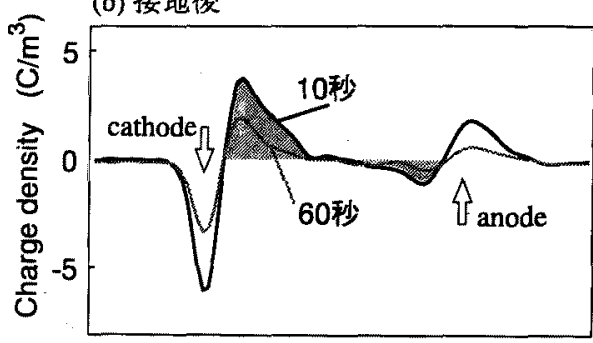

図 6 劣化前の試料(1)における架間電荷分布 -2 (a) $\mathrm{dc}$ 課電中(b)接地後

Fig. 6 Space charge distribution in sample 1 before ageing-2. (a) under dc bias voltage (b) after the short-circuits

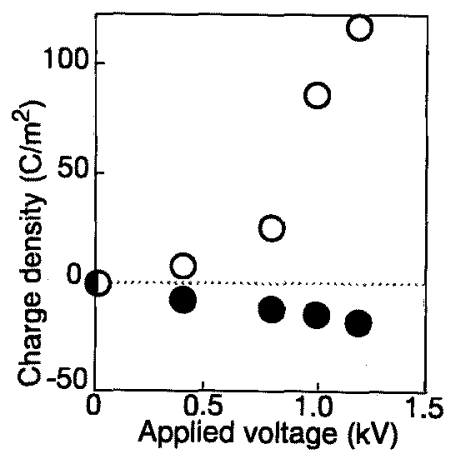

OPositive charge quantity accumulated near the cathode

- Negaitive charge quantity accumulated near anode

\section{図 7 電極近傍に蓄積した電荷量の印加電圧特性}

Fig. 7 Accumulated internal space charge quantity at each applied voltage.

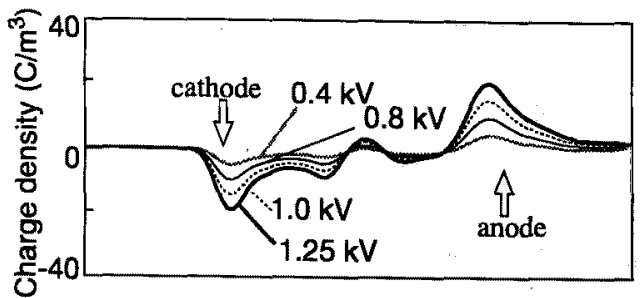

図 8 劣化前の試料(2)における空間電荷分布 各電圧に昇圧後 15 秒において観測

Fig. 8 Space charge distribution in sample 2 before ageing observed under dc bias voltage applied for about 15 sec. 
<4-2> 加湿処理による空間電荷分布の変化 課電劣化試 験に先立ち, $85^{\circ} \mathrm{C}, 70 \%$ で 18 時間予備加湿を行った試料(1) に $1.25 \mathrm{kV}$ ，印加した場合の空間電荷分布を図 9 (a)に示す。 同図中に示した前述の初期状態での結果と比較するとcathode 側の正電荷は減少し, anode 側に蓄積する負電荷が顕著に增 加した。この結果から,加湿処理を行うことにより絶縁層内 部に直流電界下で移動できる負イオンが生成されると考えら れる。一方，試料(2)の場合には図 9 (b)に示すように加湿処理 後も電荷分布に変化は見られなかった。

ここで,試料に含まれるイオン性成分を $85^{\circ} \mathrm{C}$ 水中で抽出 しイオンクロマトグラフで分析した結果試料(1)は $\mathrm{SO}_{4}^{-}$(509 $\mathrm{ppm}), \mathrm{Cl}(11.5 \mathrm{ppm}), \mathrm{NH}_{4}{ }^{+}(27.6 \mathrm{ppm})$ が検出され, 試料(2)では $\mathrm{NH}_{4}^{\prime+}(9 \mathrm{ppm})$ のみとなっている(2)。従って試料(1)において観 測された, 初期に cathode 近傍に蓄積する正電荷, 加湿劣化 後に生成される負電荷は試料(1)含まれる内部の不純物イオ ンの存在に依るものと考えられる。

\section{5. 銅イオンマイグレーションと空間電荷分布}

以上の実験結果から, 絶縁層内部の空間電荷分布と銅イオ ンマイグレーションとの関係を検討するための試料には内部 構造が均一な試料(1)で,ソルダーレジスト層の無いものを用 い, 銅蒸着で電極を作製した。この試料(1) 6 個で劣化前の空 間電荷分布を測定したところ全く同一の分布が得られてお り，試料作製にともなうばらつきはない。

上述の加湿処理後連続して $855^{\circ} \mathrm{C} \cdot 70 \% \cdot 1.25 \mathrm{kV}$ で課電加速 劣化試験を行った。20時間後に試験を中断し，室温において 直流電圧を印加した場合の空間電荷分布を図10(a)に示す。同 図中の初期, および図 9 (a)に示した加湿処理後の場合の電荷 分布と比べて anode 側（銅の蒸着電極側）から約 $40 \mu \mathrm{m}$ まで 正電荷が存在し，見掛け上 anodeが試料側へ移動したような 空間電荷分布となっている。この現象は anode 近傍に導電性 の高い領域が形成されたことが原因と推察される。

(a) 試料(1)

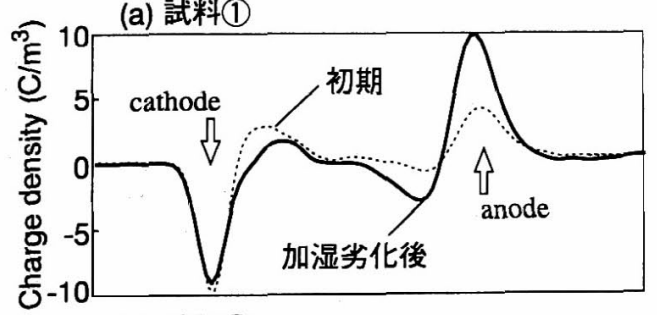

(b) 試料(2)

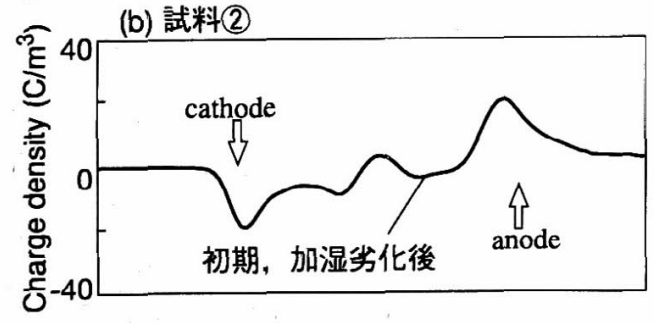

図 9 加湿劣化による空間電荷分布の変化 ((a)試料(1),(b)試料(2))

Fig. 9 Space charge distributions after aged without voltage application ((a)sample 1, (b)sample 2) 一方，同一組成の試料（anode 側は銅箔電極）を用いて同 一条件で課電劣化試験を行い試料断面の銅元素分布を波長分 散形X線分析装置付き走査電子顕微鏡で観察した結果(3), 図 10(b)のようにanode側から厚さ方向に約 $40 \mu \mathrm{m}$ のマイグレー ションが発生して扔り, 空間電荷分布に現れた導電性の高い 領域と一致することが明らかになった。

同様に加湿処理後連続して $85{ }^{\circ} \mathrm{C} \cdot 70 \% \cdot 1.25 \mathrm{kV}$ で課電加速 劣化試験を行い, 50 時間後に試験を中断した場合の空問電荷 分布と銅元素分布を比較すると図10(c),(d)に示すようにanode 近傍の導電性の高い領域, 銅元素の分布している領域とも anode 側（銅の蒸着電極側）から約 $70 \mu \mathrm{m}$ となり, マイグレ ーションの進展にともなって, 空間電荷分布が変化している ことが明らかになった。

(a) $20 \mathrm{hr}$ 課電後

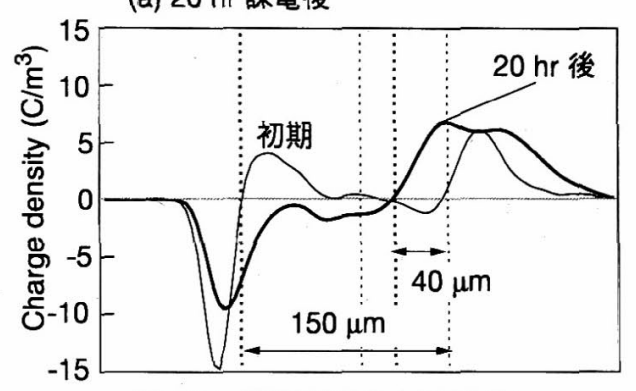

(b) $20 \mathrm{hr}$ 課電後のCu元素分布

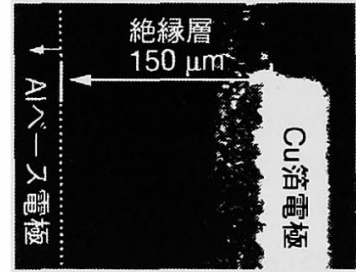

(c) $50 \mathrm{hr}$ 課電後

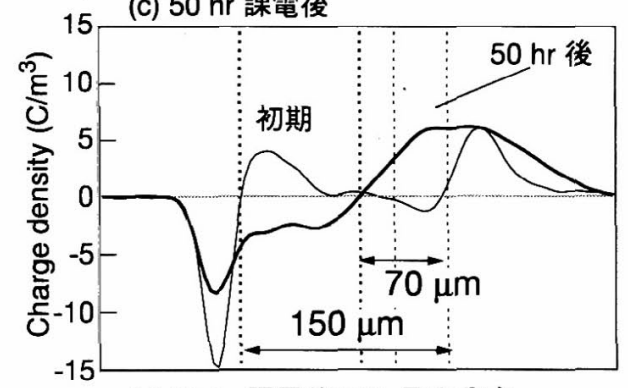

(d) $50 \mathrm{hr}$ 課電後のCu元素分布

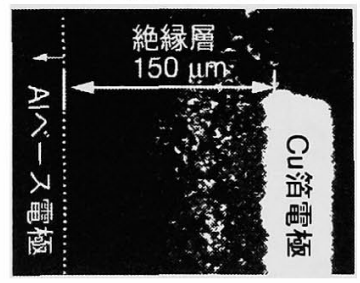

図 10 課電劣化による空間電荷分布と銅イオン分布の変化 ((a)(b) $20 \mathrm{hr},(\mathrm{c})(\mathrm{d}) 50 \mathrm{hr}$ 課電後)

Fig. 10 Space charge and Copper ion observations ((a)(b) $20 \mathrm{hr}$ and (c)(d) $50 \mathrm{hr}$ aged) 
パルス静電応力法は正・負の電荷の偏在を観測することに 適しており，化学的に活性であるが電気的に中性な励起原子 等は検出しないため元素分析結果と全く同一と考えることは できない。しかしながらマイグレーションの進展，その反応 過程を推測する上でイオンの挙動は重要であり, 空間電荷分 布の観測と，他の化学的な分析等の手法と併用することによ り詳細な検討が可能になるものと考えられる。また実用的な 面からも絶緣層内部に製造時に含まれるイオン性不純物の電 界下での挙動, 絶縁層内部の構造的な均一性の評価, 厚さ方 向に進展するマイグレーションの簡易な非破壊観測等に有効 であると考えられる。

\section{6. 結 論}

プリント回路基板絶縁層内部の空間電荷分布をパルス静電 応力法を用いて測定した。劣化前の試料を用いた測定結果か ら,プリント基板の空間電荷分布の観測には, 蒸着電極を用 いることが望ましいこと,ソルダーレジスト層には内部電荷 が存在するが明らかになった。また，高温加湿のみによる劣 化で負の内部電荷が生成されること, 課電劣化試験にともな い，正電極（銅電極）側に導電性の高い領域が形成され，そ の分布が銅元素分布の観察結果と一致すること等が明らかに なった。以上の結果から, 空間電荷分布観測はプリント基板 絶縁層の評価，開発に有効であると考えられる。

(平成 9 年10月24日受付, 平成10年 2 月27日再受付) 文 献

(1) 津久井:「プリント回路板の絶縁信頼性評価の必要性と 問題点」, 回路実装学会誌, Vol. 10, No. 2 (1995) pp. 71-73 (2) 岡本, 前田, 芳賀:「金属ベースプリント配線板におけ る銅イオンマイグレーションの検討」, 回路実装学会誌, Vol. 10, No. 2 (1995) pp. 108-112

（3）岡本, 前田, 芳賀:「金属ベースプリント配線板に㧍け る銅イオンマイグレーションと誘電特性の関倸」, 回路実 装学会誌, Vol. 12, No. 6 (1997) pp. 418-424

(4) 高田:「空間電荷計測技術の最前線」, 電学論 A, Vol. 117-A, No. 6 (1997) pp. 545-551

(5) T. Maeno and K. Fukunaga, "High-resolution PEA Charge Distribution Measurement System", IEEE Trans. Dielectrics and EI, Vol. 3, No. 6 (1996) pp. 754-757

福永 香

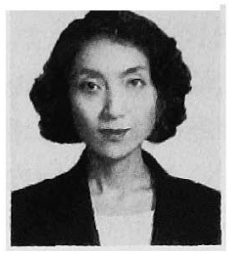

（正員） 1963年12月 14日生。1989年東京 電機大学大学院工学研究科修士課程修了。 現在, 郵政省通信総合研究所電磁環境研 究室勤務。固体誘電体表面および内部の 電荷挙動に関する研究に従事。工学博士。 静電気学会, IEEE 会貝。

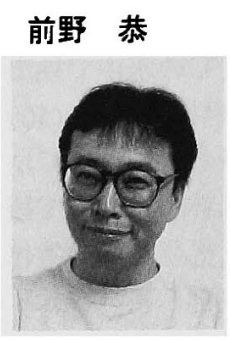

（正員） 1957 年 8 月 28 日生。1989 年武蔵 工業大学大学院工学研究科電気工学専攻博 士課程修了。現在, 郵政省通信総合研究所 光計測研究室勤務。誘電体中の空間電荷, 電界分布の計測㧍よびレーザー応用研究に 従事。工学博士。1990 年電気学会論文賞 1995 年電気学会進歩賞受賞。

岡本健次

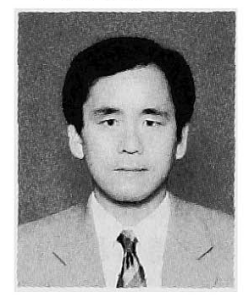

芳賀弘二

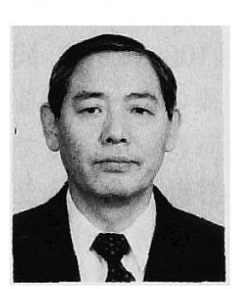

（正員） 1963 年 5 月 21 日生。 1982 年高知 県立高知工業高等学校電気科卒業。同年 㑣富士電機総合研究所入社。1 1989 年関東 学院大学工学部電気工学科卒業。主とし て電子機器, 電力機器の絶縁材料. 絶縁技 術の研究開発に従事。1991 年電気学会論 文発表賞受賞。回路実装学会会員。

（正員） 1952 年 10 月 18 日生。1971年福島 県立平工業高等学校電気科卒業。同年富 士電機製造侏)中央研究所入社。現在㑣富 士電機総合研究所主任研究員。主として 絶縁材料の研究開発に従事。 